\title{
PERSPEKTIF MARKETING POLITIK: KEGAGALAN PDIP DAN PARTAI DEMOKRAT DALAM MEMPERTAHANKAN POSISI SEBAGAI PARTAI PEMENANG PEMILU 1999 DAN PEMILU 2009
}

\author{
Agus Sutisna \\ Staf Pengajar Fakultas Ilmu Sosial Ilmu Politik \\ Universitas Muhammadiyah Tangerang \\ Email: tisna_1965@ymail.com
}

\begin{abstract}
ABSTRAK
Persaingan untuk meraih dukungan publik dalam kancah kepolitikan, khususnya event pemilu yang semakin kompetitif telah membuat partai politik dan para kandidat, baik dalam pemilu legislatif maupun eksekutif, berusaha keras mengadopsi berbagai metode dan teknik kampanye. Marketing politik (political marketing) adalah salah satu metode yang sejak era reformasi dan demokratisasi bergulir mulai banyak digunakan sebagai metode dan teknik untuk meraih dukungan pemilih dalam kampanye-kampanye Pemilu di Indonesia. Tulisan ini merupakan telaah teoritik sederhana mengenai pendekatan marketing politik yang kemudian digunakan sebagai perspektif untuk menjelaskan kegagalan PDI Perjuangan dan Partai Demokrat dalam mempertahankan posisi sebagai partai pemenang Pemilu.

Kajian ini menggunakan metode kualitatif, dengan sumber data diperoleh melalui studi kepustakaan dan pengamatan fenomenologis terhadap dinamika perjalanan partai politik, khususnya PDIP dan Partai Demokrat dari Pemilu ke Pemilu dalam kepolitikan Indonesia mutakhir melalui berbagai saluran media yang dapat diakses. Hasil kajian menunjukkan bahwa pendekatan marketing politik padaumumnyamemilikipotensiyangefektifsebagaimetode untukmemperkenalkan dan memasarkan produk politik (partai, kandidat, program dll), meraih simpati publik, dan akhirnya memperoleh dukungan pemilih dan merawat loyalitas mereka; dengan catatan prinsip-prinsipnya dipraktekkan secara utuh, baik dan tepat, serta didukung oleh riset dan tim yang handal. Sebaliknya, ketidakutuhan penerapan prinsip-prinsip marketing politik dapat mengakibatkan kegagalan partai politik dalam menjaga stabilitas partai dan mempertahankan kemenangannya dalam suatu
\end{abstract}


Pemilu pada Pemilu berikutnya seperti dialami oleh PDIP dan Partai Demokrat.

Kata Kunci: komunikasi politik, kampanye pemilu, marketing politik, pull marketing, push marketing, pass marketing, PDIP, dan Partai Demokrat.

\section{ABSTRACT}

The competition to reach public support in politic, particularly in election which more and more competitive had made the political parties and the candidate trying hard to adopted of various method and campaign technic. Political marketing is one of method that has been used as technic to achieve constituen support in elections in Indonesia. This article is teoritical simple analysis about political marketing approach that used as perspective to explain about failing Indonesian Struggling and Democracy Party (PDI Perjuangan) and Democrat Party (Partai Demokrat) to keep going the position as election winner.

This research using qualitative method with data and information got by literature and phenomeology observation to political parties dynamic, especially to PDI Perjuangan and Partai Demokrat in periodical elections in current Indonesia 's Politic from various media. The result shown that political marketing approach generally has potention effectively as a method to recognizing and to marketing the political product such as parties, candidate, programme, etc, to echieve public sympaty and to obtain public vote and to maintance their loyalty provided that the principles use intact, precise and supported by research and great team. Otherwise, unintact using the principles of political marketing will impact failing the political parties to keep the stability and keep going to its winning in next election that has been occured by PDI Perjuangan and Partai Democrat.

Keywords: political communication, campaign, political marketing, pull marketing, push marketing, pass marketing, PDIP, Partai Demokrat.

PENDAHULUAN

\section{Latar Belakang Masalah}

Era demokrasi yang terus menguat dalam kancah kepolitikan Indonesia pasca runtuhnya rezim otoritarian orde baru telah melahirkan fenomena perburuan kekuasaan dan persaingan untuk meraihnya yang semakin masif dan kompetitif dari waktu ke waktu. Hal ini ditandai misalnya oleh pertumbuhan partaipartai politik baru setiap kali perhelatan lima tahunan Pemilu akan 
digelar yang tidak menunjukkan gejala penyusutan, meskipun diketahui adalah bukan perkara mudah untuk dapat meraih simpati dan dukungan publik kemudian memperoleh konstituen, lalu mengantarkan partaipartai baru itu lolos dari pintu parliamentary threshold dan masuk ke dalam parlemen.

Penanda untuk gejala yang sama juga ditunjukkan oleh semakin bergairahnya individu-individu warga yang peduli dan berminat pada kehidupan politik serta masa depan negara/daerahnya, atau yang sekedar "merasa" memiliki kompetensi, sumberdaya atau massa pendukung untuk mengadu "peruntungan" di pentas pemilu dengan memajukan diri, keluarga atau kerabatnya sebagai para kandidat, baik pemilu legislatif maupun pemilu eksekutif. Meskipun, lagi-lagi, mereka juga tahu persis, bahwa untuk dapat memenangi kontestasi yang serba kompetitif itu bukanlah perkara yang mudah.

Persaingan yang semakin kompetitif dan tak mudah untuk melewatinya dengan memenangi kontestasi itu telah dan tampaknya akan terus mendorong partai politik dan para kandidat untuk mencari dan menggunakan berbagai cara dan strategi yang dibenarkan secara hukum sekaligus dimungkinkan dari sisi ketersediaan sumberdaya yang dimiliki. Kampanye, dalam pengertian konvensional maksudnya, tentu merupakan jalan yang selama ini sudah digunakan untuk kebutuhan memenangi kontestasi itu. Tetapi kampanye yang monoton, tidak cukup kreatif, dan hanya dilakukan dengan cara-cara tradisional-konvensional tampaknya akan menemui jalan buntu dan tidak efektif lagi pada saat ini dan kedepan. Setidaknya, cara-cara klasik ini akan kalah bersaing dengan metode-metode baru yang lebih kreatif dan lebih canggih, baik yang menggunakan saluran (chanel) media konvensional seperti surat kabar, baligo, spanduk, poster, dll, maupun dan terutama yang memaksimalkan pemanfaatan saluran-saluran media elektronik seperti radio, televisi, laman-laman online dan media sosial.

Dalam kerangka fenomena itulah kehadiran pendekatan, metode, prosedur, dan teknik-teknik marketing (pemasaran) dalam dunia politik yang secara konseptual lazim dikenal dengan istilah Political Marketing (pemasaran politik) menjadi penting dan menarik diperbincangkan. Tulisan ini mendiskusikan dan menganalisis kegagalan PDIP dan Partai Demokrat sebagai partai pemenang Pemilu (pada tahun 1999 bagi PDIP dan tahun 2009 bagi Partai Demokrat) dari sudut pandang marketing politik.

Pada bagian akhir tulisan akan dikemukakan beberapa catatan kritis terhadap penerapan pendekatan marketing politik dalam kerangka dinamis kehidupan politik, khususnya dalam konteks persaingan untuk memperoleh dukungan pemilih pada 
perhelatan Pemilu. Konsep marketing politik dalam paper ini diposisikan sebagai bagian dari terma Komunikasi Politik, sekaligus merupakan salah satu varian dari bentuk kegiatan Kampanye Politik dan Kampanye Pemilu.

\section{Perumusan Masalah}

Berdasarkan uraian latar belakang tersebut diatas, selanjutnya paper ini akan berusaha menjawab dan menjelaskan 3 (tiga) pokok permasalahan/pertanyaan penelitian berikut ini :

1. Bagaimana posisi pendekatan/perspektif Marketing Politik sebagai instrumen untuk memenangi kontestasi politik?

2. Bagaimana pendekatan/perspektif Marketing Politik menjelaskan kegagalan PDI Perjuangan dalam mempertahankan posisinya sebagai partai pemenang Pemilu 1999 pada pelaksanaan Pemilu 2004?

3. Bagaimana pendekatan/perspektif Marketing Politik menjelaskan kegagalan Partai Demokrat dalam mempertahankan posisinya sebagai partai pemenang Pemilu 2009 pada pelaksanaan Pemilu 2014 ?

\section{Metode}

Kajian ini menggunakan pendekatan kualitatif dengan data dan informasi diperoleh melalui studi kepustakaan dan pengamatan fenomenologis terhadap dinamika perjalanan partai politik, khususnya PDIP dan Partai Demokrat dari satu pemilu ke pemilu berikutnya sejak era reformasi.

\section{KAJIAN TEORITIK}

\section{Hakekat dan Ruang Lingkup Marketing Politik}

Sebagai sebuah disiplin kajian, marketing politik merupakan kajian yang bersifat interdisipliner. Paling tidak terdapat tiga bidang perspektif ilmu yang terlibat dan saling melengkapi kajian marketing politik, yaitu: ilmu politik, ilmu komunikasi, dan ilmu marketing (manajemen marketing). Itu sebabnya, para teoritisi yang merintis dan mengembangkan kajian ini juga secara umum berasal dari ketiga latar belakang keilmuan tersebut ${ }^{87}$ sebagaimana akan dipaparkan pada bagian ketiga paper ini.

87. Lihat uraian deskriptif perkembangan kajian Marketing Politik dalam Nyarwi Ahmad, Manajemen Komunikasi Politik dan Marketing Politik: Sejarah, Perspektif dan Perkembangan Riset, Yogyakarta : Pustaka Zaman, 2012, hal. 333-347. 
Namun demikian, dalam memberikan rumusan hakekat dari pengertian tentang marketing politik, para ahli yang berbeda latar belakang disiplin keilmuan itu tidak menunjukkan perbedaan yang berarti, kecuali dalam memberikan penekanan pada aspekaspek yang terdapat di dalam konsepnya. Philip Kotler (1982) misalnya, lebih memberikan penekanan pada proses transaksi yang terjadi antara pemilih dan kandidat. Lock dan Harris (1996) menyarankan agar political marketing memperhatikan proses positioning. Sementara Dominic Wring (1997) lebih konsen pada aspek penggunaan riset opini dan analisis lingkungan. ${ }^{88}$

Bruce I. Newman (1999) misalnya, ${ }^{89}$ mendefinsikan marketing politik sebagai penggunaan prinsipprinsip dan prosedur marketing dalam kampanye politik yang dilakukan oleh individu maupun organisasi. Marketing politik menurutnya merupakan penggunaan teori dan konsep marketing dalam sistem politik. Prosedur di sini termasuk analisis, perkembangan, pelaksanaan dan manajemen strategi kampanye yang dilakukan oleh kandidat, partai politik, pemerintah, para pelobi (lobbyist) dan kelompokkelompok kepentingan yang dimaksudkan untuk menggerakan : 1) opini publik; 2) ideologi tertentu; 3) memenangkan pemilu; 4) mendapatkan dukungan dalam penyusunan legislasi; dan 5) referendum untuk merespons ragam kebutuhan dan keinginan masyarakat atau kelompok tertentu dalam masyarakat.

Pandangan yang tidak jauh berbeda dikemukakan oleh Jennifer Lees-Marshment dan O' Cass. LeesMarshment $^{90}$ menyatakan, bahwa political marketing merupakan hasil dari perkawinan antara prinsip-prinsip marketing dan politik, yang secara empirik hal ini direpresentasikan melalui persebaran pengaruh arena politik oleh prinsip-prinsip marketing. Dalam pandangannya, kombinasi ini akan memberikan gambaran yang lebih utuh tentang perilaku partai politik.

Sementara O'Cass ${ }^{91}$ menyatakan bahwa political marketing merupakan penggunaan teknik-teknik marketing dalam partai politik dimaksudkan untuk meningkatkan kemampuan mereka dalam mempengaruhi pemilih melalui serangkan analisis pasar,

88. Adman Nursal, Political Marketing : Strategi Memenangkan Pemilu, Jakarta : Gramedia Pustaka Utama, 2004, hal.7-8

89. Op. Cit., hal.344

90. Lees-Marshment, Jennifer, Marketing Politics : Prinsiples and Application, London : Routledge Publication, 2009, Hal. 693.

91. Op. Cit., hal. 343. 
perencanaan, implementasi, dan kontrol terhadap proses kampanye politik dan pemilihan. Berdasarkan hal ini maka menurutnya, tujuan utama dari political marketing adalah meningkatkan kemampuan partai politik dan juga pemilih untuk menghasilkan keputusan politik dan kebijakan publik yang memberikan kepuasan bagi keduanya.

Kemudian sebagaimana dikutip Ahmad, O'Cass menggunakan model pertukaran dalam mendifinisikan political marketing. Maksud model ini ialah bahwa, ketika seorang pemilih sudah menentukan dan memberikan pilihannya, maka sebuah transaksi dalam political marketing telah terjadi. Sebagai imbalan dari apa yang dilakukan pemilih tersebut, kandidat maupun partai politik harus memberikan orientasi pemerintahan dan kebijakan publik terbaiknya kepada mereka setelah pemilihan berlangsung. Dalam pandangan O'Cass, prinsip-prinsip marketing dapat dipergunakan dalam proses politik, terkait dengan kepentingankepentingan khusus dimana proses transaksi tersebut dibuat dan dinilai.

Dalam pada itu, jika dilihat dari sudut pandang komunikasi politik, marketing politik merupakan bagian dari komunikasi politik, yang menurut Harold D. Laswell adalah suatu proses "who says what in which chanel to whom with what effects"; siapa mengatakan apa, melalui saluran apa, kepada siapa, dengan akibat apa. ${ }^{92}$ Dalam konteks ini marketing politik juga mengkaji perihal aktor-aktor politik (partai maupun kandidat); apa yang dikatakannya; melalui saluran atau media apa; kepada siapa pesan komunikasi itu ditujukan; dan apa akibat atau target yang hendak dicapainya.

Sebagaimana dikemukakan Philip J. Maarek, ${ }^{93}$ bahwa political marketing merupakan metode umum dalam komunikasi politik yang digunakan sebagai sarana dalam mencapai tujuan komunikasi politik. Selain itu, menurutnya penggunaan logika marketing dalam dunia politik merupakan sarana untuk mengelaborasi kebijakan-kebijakan dalam komunikasi politik sebagai bentuk trend desain strategi global sebagai wujud modernisasi komunikasi politik. Kemudian, merujuk pada pendapat Butler dan Collins, Mareek berpendapat bahwa dalam komunikasi politik, ada beberapa persamaan dengan dunia bisnis. Produk dari komunikasi

92. Dan Nimmo, Komunikasi Politik : Komunikator, Pesan, dan Media, Bandung : Rosda Karya, 1999, Hal. 13.

93. Mareek, Philip J., Political Marketing and Communication, London : John Libbey and Co., 1995, Hal.2. 
politik menurutnya berupa: 1) ideologi yang menjadi platform partai politik dan yang menjadi dasar kebijakan partai politik; 2) kemimpinan parpol, kandidat dan kader-kader partai politik; 3) anggota-anggota partai politik secara umum.

Dari beberapa pandangan ahli diatas, kiranya dapat disimpulkan bahwa konsep marketing politik (political marketing) pada hakekatnya merupakan penerapan atau penggunaan prinsip-prinsip dan teknikteknik marketing (pemasaran) komersial/bisnis dalam aktifitas politik; aktifitas untuk memperoleh kepercayaan publik, dipilih oleh electorate (pemilih), memenangi kontestasi, dan akhirnya memperoleh kekuasaan/ jabatan politik, dan sedapat mungkin mempertahankannya di kemudian hari melalui pemeliharaan loyalitas para pemilih. Atau dalam rumusan yang paling sederhana, seperti dikemukakan oleh Firmanzah, ${ }^{94}$ bahwa marketing politik adalah penggunaan metode marketing dalam bidang politik.

Sebagai sebuah disiplin kajian, marketing politik memiliki ruang lingkup yang khas. Bruce I. Newman dalam Nyarwi Ahmad ${ }^{95}$ memetakan ruang lingkup kajian marketing politik ini kedalam beberapa domain.
Pertama, manajemen kampanye politik, dimana di dalamnya mengkaji bagaimana manajemen kampanye politik yang dilakukan oleh para manajer dan konsultan politik, manajemen sukarelawan pendukung (volunteer) kandidat dan parpol, media placement dan fundrising pendanaan politik. Kedua, analisis terhadap arena pasar politik. Di sini termasuk penggunaan survei oleh kandidat dan parpol dalam kampanye politik, riset pasar menjelang kampanye politik dan pemilu, exit polls dan kampanye politik, riset prediksi model perilaku pemilih, menyusun dan mengembangkan iklan politik yang efektif, dan analisis terhadap nilai-nilai yang mempengaruhi perilaku politik pemilih, dan juga kajian bagaimana mempengaruhi para pemilih Golput.

Ketiga, kajian tentang pengembangan strategi politik. Di sini termasuk kajian tentang image verbal dan non-verbal yang dibangun oleh parpol dan kandidat, marketing langsung (direct marketing), debat politik di televisi, segmentasi pemilih dan positioning kandidat, iklan politik, televisi dan pemilu elektoral, dan dampaktelevisi bagi demokratisasi politik. Keempat, bagaimana memilih dan menentukan strategi kampanye

94. Firmanzah, Marketing Politik : Antara Pemahaman dan Realitas, Jakarta : Yayasan Obor Indonesia, 2008, Hal.12

95. Op. Cit., Hal. 
politik. Beberapa kajian yang dilakukan di sini antara lain, tentang ragam strategi kampanye politik, kampanye politik yang dilakukan oleh para lobbyist, kelompok kepentingan dan pemerintah, termasuk di dalamnya adalah kampanye permanen (permanent campaign). Kelima, isu-isu kontemporer dalam marketing politik yang terkait dengan penggunaan news media, problem pendanaan dalam marketing politik, marketing politik dan propaganda, dan juga politik uang.

\section{Positioning, Elemen dan Strategi Marketing Politik}

Bertolak dari uraian hakekat dan ruang lingkup kajian diatas, tampak jelas bahwa marketing politik memiliki cakupan yang jauh lebih luas dari kampanye pemilu, meskipun keduanya sama-sama merupakan bentuk komunikasi politik. Walaupun demikian, hingga batas tertentu, teknik-teknik di dalam marketing politik dapat digunakan untuk kepentingan kampanye yang berjangka pendek oleh partai-partai terutama dalam menghadapi dan menjelang perhelatan konstestasi Pemilu. Dari perspektif waktu, kalaupun tidak permanen, penggunaan marketing politik juga jauh lebih panjang durasinya dibandingkan dengan kampanye politik/kampanye pemilu.
Perbedaan lain, target dan aktifitas marketing politik juga lebih luas dan menyeluruh dibandingkan dengan kampanye pemilu yang targetnya sederhana, yakni meraih sebanyak mungkin suara pemilih dalam Pemilu. Sedangkan marketing politik, selain target perolehan suara, juga mencakup aktifitas-aktifitas politik jauh sebelum dan sesudah pelaksanaan Pemilu. Sebelum Pemilu, aktifitas marketing politik meliputi antara lain masalah positioning partai dan kandidat, riset untuk pemetaan atau segmentasi pasar, analisis kekuatan dan kelemahan para kompetitor, dll. Sementara pasca Pemilu, aktifitas marketing politik mencakup antara lain ikhtiar-ikhtiar politik untuk memelihara dukungan dan merawat loyalitas para pemilih dengan cara memberikan kepuasan politik kepada mereka melalui berbagai kebijakan yang mungkin menjadi bagian dari materi kampanye dalam Pemilu.

Salah satu aspek penting dalam marketing politik, terutama ketika metode marketing politik hendak digunakan untuk kepentingan kampanye pemilu, adalah masalah positioning. Konsep positioning ini, sudah pasti diadopsi dari dunia marketing. Dalam dunia marketing, menurut Rhenald Kasali, ${ }^{96}$ positioning adalah mencari jendela di otak konsumen;

96. Kasali, Rhenald, Membidik Pasar Indonesia : Segmentasi, Targeting, Positioning, Jakarta : Gramedia Pustaka Utama, 1998.

118 Cosmogov, Vol. 2 No. 1, April 2016 
dan dalam konteks political marketing, positioning adalah mencari jendela di otak pemilih. ${ }^{97}$ Bagi orang-orang marketing, positioning sangat menentukan keberhasilan pemasaran. Kasali (1996) menyatakan bahwa positioning merupakan mantra yang penting bagi orang-orang pemasaran di akhir abad ke-20. ${ }^{98}$ Dalam dunia politik, studi yang dilakukan Plasser, dkk dalam Bruce Newman ${ }^{99}$ menyebutkan, bahwa $66 \%$ dari konsultan kampanye politik di Eropa Barat dan 70\% dari konsultan kampanye politik di Amerika Serikat mengakui positioning sebagai salah satu faktor yang menentukan keberhasilan suatu kampanye.

Dalam pengertian yang lebih utuh, positioning dalam konteks marketing politik adalah tindakan untuk menancapkan citra tertentu ke dalam benak para pemilih agar tawaran produk politik dari suatu kontestan memiliki posisi khas, jelas dan meaningful. Positioning yang efektif akan menunjukkan perbedaan nyata dan keunggulan sebuah kontestan dibandingkan dengan kontestan pesaing. Positioning secara tidak langsung juga mendefinisikan pesaing, bahwa pesaing tidak tidak dapat mewujudkan tawaran-tawaran produk politik tertentu sebaik pihak yang mencanangkan positioning tersebut.

Merujuk pada Nursal, ${ }^{100}$ agar menjadi kredibel dan efektif, positioning harus dijabarkan dalam bauran produk politik yang meliputi 4P: Policy, Person, Party dan Presentation. Policy adalah tawaran program jika terpilih kelak; policy merupakan solusi yang ditawarkan kontestan (partai atau kandidat) untuk memecahkan masalah kemasyarakatan berdasarkan isu-isu yang dianggap penting oleh pemilih. Person adalah kandidat legislatif atau eksekutif yang akan dipilih melalui Pemilu. Party, sebagaimana policy dan person, selain sebagai pelaku marketing politik (manajemen partai tentunya) pada dasarnya juga merupakan produk politik yang harus dikelola dengan baik dalam kerangka melakukan positioning.

97. Nursal, Op.Cit., Hal. 142.

98. Op. Cit.

99. Newman, Bruce I., (ed), Handbook of Political Marketing, London, New Delhi : Sage Publication Inc., 1999.

100. Nursal, Op. Cit., Hal. 
Terakhir adalah Presentation, yakni penyajian ketiga substansi produk politik diatas (policy, person dan party) kepada khalayak. Presentasi ini penting dan bisa sangat menentukan hasil suatu kampanye, karena ia menyangkut soal kemasan dan teknik penyajian. Produk-produk yang unggul bisa tak laku di pasar jika cara penyajian dan kemasannya dibuat asal dan alakadar. Pada titik inilah dunia marketing politik membutuhkan para konsultan handal yang bekerja mulai dari tahapan riset untuk mendesain produk, mendisain kemasan, hingga ke berbagai strategi dan teknik presentasi produk politik itu kepada publik.

Kemudian merujuk pada uraian Shea dan Burton, ${ }^{101}$ strategi pemasaran yang tidak lain merupakan kegiatan menyampaikan dan menyajikan produk-produk politik itu kepada khalayak dapat dibedakan ke dalam tiga jenis pendekatan, yaitu: pull marketing, push marketing, dan pass marketing.

Pull marketing adalah strategi pemasaran atau penyampaian produk politik kepada pemilih melalui saluran media massa (bisa cetak, elektronik atau online media). Shea dan Burton mengingatkan perlunya 5 (lima) syarat dalam pendekatan ini agar menuai hasil yang diharapkan, yaitu : pertama konsistensi pada disiplin pesan; kedua efesiensi biaya terutama menyangkut pemasangan iklan; ketiga momentum; keempat pengemasan; kelima permainan ekspektasi.

Push marketing adalah strategi pemasaran atau penyampaian produk politik kepada pemilih secara langsung, tidak melalui saluran media. Shea dan Burton kemudian mengemukakan beberapa kelebihan dari strategi marketing ini. Pertama, strategi ini dapat mengarahkan para pemilih menuju suatu tingkat kognisi yang lebih baik dibandingkan dengan bentuk kampanye lainnya. Kedua, kontak langsung dalam strategi ini memungkinkan terjadinya komunikasi dua arah, melakukan persuasi dengan pendekatan verbal dan non-verbal yang bisa lebih bermakna dan berkesan bagi pemilih. Ketiga, strategi ini dapat menghumaniskan kandidat. Keempat, strategi ini dapat meningkatkan antusiasme massa dan menarik perhatian media massa.

Pass marketing adalah strategi pemasaran atau penyampaian produk

101. Shea, D.M dan Burton, M.J., Campaign Craft : The Strategies, Tactics, and Art of Political Campaign Management, Westport : Preager, 2001, hal 114. 
politik kepada para influencer, yakni individu (informal leader) atau kelompok yang memiliki akses dan pengaruh kuat sekaligus menjadi acuan para pemilih dalam menentukan pilihannya pada suatu Pemilu.

\section{Model Marketing Politik Lees- Marshment}

Di kalangan para perintis dan pengembang studi marketing politik sebagaimana dikemukakan di depan, Jennifer Lees-Marshment merupakan salah seorang diantara mereka yang paling banyak dikutip dan dielaborasi pemikiran-pemikirannya. Salah satu diantara pemikirannya adalah menyangkut masalah strategi partai sebagai pelaku utama marketing politik. Di dalam bukunya, Political Marketing and British political Parties (2001), yang kemudian dielaborasi lagi bersama sejawatnya, Darren G. Lilleker dalam buku Political Marketing: A Comparative Perspective (2005) yang mereka sunting, LeesMarshment memformulasikan tiga model marketing politik yang dilakukan oleh partai-partai politik. Yaitu model Product Oriented Party (POP), Sales Orientde Party (SOP), dan Market Oriented Party (MOP).
Ketiga model ini menurut LessMarshment telah dipraktekan di berbagai negara demokrasi dalam rangka kompetisi dan kontestasi pemilihan umum. ${ }^{102}$

Model POP adalah model marketing politik yang didasarkan pada produk (product oriented) politik yang dimiliki partai sendiri; mulai dari platform atau ideologi, program atau rancangan kebijakan, aktor politik termasuk para kandidat. Partai-partai yang memilih model ini biasanya merasa yakin bahwa produk-produk politik mereka bernilai dan unggul dibandingkan produk yang sama yang dimiliki para kompetitornya. Atas dasar keyakinan ini, partai biasanya menolak segala potensi dan semangat perubahan yang diinginkan pemilih.

Model POP bisa efektif manakala partai memiliki produk-produk politik yang secara ril dan obyektif memang unggul, misalnya ketokohan dari para pemimpin partainya, atau rancangan program dan kebijakan partai. Model ini, karenanya juga tidak merasa penting untuk melakukan riset pasar guna mengetahui respon publik dan peluang elektabilitasnya dalam Pemilu. Namun sebaliknya, partai dengan pilihan model ini dengan mudah bisa mengalami kekalahan

102. Ahmad, Op.Cit., Hal. 338. 
ketika produk-produk politiknya tidak memiliki nilai jual di pasar politik, sementara mereka tidak membuka peluang bagi masuknya gagasangagasan perubahan yang dikehendaki konstituennya.

Jika model POP mendasarkan diri pada, sekaligus mengandalkan produk politik yang dimiliki oleh partai sebagai aset, maka model SOP lebih menekankan pada orientasi penjualan (sales oriented). Partai dengan pilihan model ini tidak terlalu merisaukan produk-produk politik yang dimiliki (taruhlah, misalnya produk itu tidak memiliki keunggulan kompetitif di pasar politik); konsen mereka adalah bagaimana agar produk-produk politik itu -selemah apapun kualitasnya, dapat dipasarkan sedemikian rupa, diterima dan diminati, kemudian akhirnya dipilih oleh konsumen (electorate, pemilih).

Berbeda dengan model POP, model SOP menganggap riset pasar untuk mengetahui respon publik sebagai hal yang penting. Namun demikian, hasil riset menyangkut harapan publik atas positioning atau performa partainya tidak akan mengubah produk-produk politik mereka. Artinya, partai tidak perlu menyesuaikan diri dengan keinginan pasar. Tetapi partai akan berusaha maksimal untuk membujuk konstituen sedemikian rupa agar bersedia menerima produk-produk yang mereka miliki; meminatinya, kemudian memilihnya. Oleh sebab itu, dalam model ini, berbagai saluran/media marketing menjadi sangat penting, karena melalui saluran/media inilah partai akan memaksimalkan ikhtiar marketingnya untuk produk-produk politik mereka.

Model yang terakhir dari LeesMarshment adalah MOP, model pemasaran politik yang berorientasi pada pasar (market oriented); dalam hal ini tentu yang dimaksud adalah aspirasi dan kebutuhan publik. Berbeda dengan kedua model terdahulu, model ini menganggap riset politik sangat penting. Bahkan riset akan menjadi rujukan mereka dalam mendesain produk-produk politiknya yang akan ditawarkan kepada konsumen. Oleh sebab itu, dalam model ini partai akan berusaha menyesuaikan diri, baik positioning maupun desain produknya, dengan keinginan dan kebutuhan konsumen. Hal ini berbeda secara diamteral dengan model SOP, dimana partai yang akan berusaha keras "mengadaptasikan" keingingan dan kebutuhan konsumen dengan positioning dan desain produk mereka melalui berbagai strategi kampanye yang dapat dilakukan.

Dalam kaitan ini, LeesMarshment mengingatkan agar partaipartai yang memilih model strategi MOP benar-benar dapat memastikan bahwa apa yang mereka tawarkan/ janjikan kepada konsumen dapat diwujudkan nantinya. Sebab jika tidak, hal ini akan berdampak buruk 
bagi partai di kemudian hari. Para konsumen atau pemilih akan kecewa dan meninggalkan partai, bahkan dalam jangka panjang. ${ }^{103}$

\section{KEGAGALAN PDIP DAN \\ PARTAI DEMOKRAT \\ MEMPERTAHANKAN POSISI SEBAGAI PARTAI PEMENANG PEMILU}

Berdasarkan kombinasi sejumlah perspektif marketing politik tersebut diatas, pada bagian ini akan dianalisis 2 (dua) partai politik dalam kerangka kontestasi dan dinamika perjalanan Pemilu di Indonesia pasaca Orde Baru. Kedua partai itu adalah PDI Perjuangan dan Partai Demokrat; masingmasing mewakili partai warisan Orde Baru dan mewakili partai yang lahir pada masa reformasi ${ }^{104}$.

Kedua partai ini, sama-sama pernah menjadi partai pemenang Pemilu. ${ }^{105}$ PDIP menang pada Pemilu 1999 dengan raihan suara lebih dari $1 / 3$ suara nasional, yakni 33,74\% (setara dengan 153 kursi di DPR RI), dan Partai Demokrat menang pada Pemilu 2009 dengan raihan suara sebesar 20,85\% (setara dengan 148 kursi di DPR RI). Kedua partai ini juga sama-sama pernah memerintah (the rulling party), meski untuk PDIP kesempatan memerintah itu sempat "tertunda" karena kalah adu strategi dengan Poros Tengah yang digagas Amien Rais. Dan kedua partai ini juga sama-sama memiliki figur sentral dan icon partai yang memegang kendali penuh atas kebijakan dan arah kepolitikan partainya. PDI Perjuangan memiliki sosok Megawati; Partai Demokrat memiliki sosok SBY.

Tetapi yang paling penting dalam konteks analisis ini adalah, bahwa kedua partai juga pernah mengalami nasib yang sama, yaitu : satu periode memerintah setelah kemenangannya dalam Pemilu Legislatif, baik PDIP maupun Demokrat menderita kekalahan pada Pemilu berikutnya. PDIP kalah dalam Pemilu 2004 setelah memenangi Pemilu 1999 dan memerintah antara tahun 2001-2004; dan Demokrat kalah dalam Pemilu 2014 setelah memenangi Pemilu 2009 dan memerintah pada periode 2009-2014.

Dari sudut pandang marketing politik, mengapa dan bagaimana kedua partai ini mengalami kekalahan; gagal mempertahankan stabilitas

103. Lees-Marshment, Op.Cit., Hal. 1078.

104. Bambang Setiawan dan Bestian Nainggolan (eds), Partai-Partai Politik Indonesia : Ideologi dan Program 2004-2009, Jakarta : Gramedia Pustaka Utama, 2004.

105. Www.kpu.go.id dan www.rumahpemilu.org., diakses tanggal 7 Januari 2015. Selanjutnya, semua data baik kualitatif maupun kuantitatif mengenai proses dan hasil Pemilu dalam studi ini didasarkan pada dua sumber laman ini. 
prestasi raihan suara partai dan gagal merawat loyalitas pemilih, justru pada Pemilu dimana kedua partai ini sedang memerintah? Berikut ini penulis akan mencoba menguraikan dan menganalisisnyadenganmengkombinasikan berbagai perspektif para ahli marketing politik yang pokok-pokok pikirannya telah dikemukakan di depan.

\section{PDI Perjuangan:}

Kegagalan Mewujudkan Positioning sebagai "Partai Wong Cilik"

Pemilu 1999, pemilu pertama sejak Orde Baru runtuh, PDIP memperoleh kemenangan besar (33,74\%; setara dengan 153 kursi di DPR RI pada waktu itu, dan mengungguli Golkar yang hanya memperoleh 22,44\%; setara dengan 120 kursi). Meski gagal mengantarkan Megawati menjadi Presiden karena kalah strategi politik oleh Amien Rais dkk melalui ide Poros Tengah-nya dalam pemilihan Presiden-Wakil Presiden di MPR, kemenangan ini menjadi tonggak sejarah penting bagi perjalanan PDIP. Salah satu faktor kemenangan ini adalah karena simbol perlawanan rakyat terhadap rezim otoritarian Orde Baru yang melekat dalam pribadi Megawati sebagai Ketua Umum PDI yang tidak dikehendaki oleh pemerintah, yang kemudian dideklarasikan menjadi PDI Perjuangan, 14 Pebruari 1999.

Pasca Pemilu 1999 dan secara umum di tahun-tahun awal reformasi itu, pendekatan marketing politik boleh jadi belum disadari sebagai suatu strategi penting untuk membangun wibawa partai, menjaga stabilitas, dan merawat loyalitas konstituennya. Namun demikian, Megawati dan para senior PDIP sadar betul bahwa label sebagai simbol perlawanan rakyat itu adalah sesuatu yang sangat berarti bagi partai. Itu sebabnya, sejak kemenangan besar pada Pemilu 1999 itu, PDIP kemudian melabeli dirinya secara "formal" sebagai partai-nya "Wong Cilik"106. Dalam perspektif marketing politik, inilah yang disebut sebagai positioning. Dalam konteks ini PDIP berusaha memposisikan dirinya di hadapan publik sebagai partai yang akan membela dan bekerja untuk rakyat kecil (wong cilik), atau meminjam kembali ungkapan Nursal (2004), PDIP berusaha "menancapkan citra ke dalam benak para pemilih" sebagai partainya orang-orang kecil yang selama kekuasaan Orde Baru

106. Www.pdiperjuangan.or.id., diakses tanggal 7 Januari 2015.

124 CosmoGov, Vol. 2 No. 1, April 2016 
terpinggirkan. Positioning ini juga secara tidak langsung mendefinisikan, bahwa para pesaingnya (partai-partai lain) bukanlah partai yang akan mengabdi dan bekerja untuk wong cilik.

Masalahnya kemudian, pelabelan (tagline) sebagai partainya "Wong Cilik" yang dalam perspektif marketing politik sudah memenuhi prasyarat sebagai cara positioning yang baik itu tidak disertai dengan manajemen bauran produk (mix product management) yang utuh dan baik. Para ahli marketing politik merumuskan, bahwa positioning yang khas, jelas dan meaningful haruslah bersumber dari faktor-faktor pembeda yang dimiliki sebuah partai dibandingkan dengan partai lainnya. Tetapi tidak semua faktor pembeda akan menghasilkan positioning yang efektif. Beberapa faktor pembeda yang bisa memberikan efek positif dan efektif terhadap pilihan positioning antara lain adalah : important (penting), distinctive (istimewa, khas), communicable (mudah dikomunikasikan) dan preemptive (tidak gampang ditiru). Label "Wong Cilik" jelas memiliki semua prasyarat pembeda itu.
Masalahnya, sekali lagi, PDIP tidak mampu mengelola (atau mungkin memang tidak melakukannya sama sekali) dengan baik empat bauran produk marketing politik, yakni: policy, person, party dan presentation. Seperti dimaklumi kemudian, Megawati akhirnya menggantikan Gus Dur sebagai Presiden setelah almarhum Gus Dur dimakzulkan oleh MPR. Selama kurang lebih 3 (tiga) tahun memimpin pemerintahan (2001-2004), tidak banyak kebijakan (policy) MegawatiPDIP yang berpihak pada wong cilik; yang terjadi justru pemerintah banyak melego aset-aset nasional kepada asing, diantaranya Indosat, Telkom, kapal tanker, Bank Danamon, BCA dan Bank Internasional Indonesia dll. ${ }^{107}$ Megawati juga melepaskan pulau Sipadan dan Ligitan; belum lagi skandal BLBI yang merugikan negara hingga ratusan trilyun rupiah ${ }^{108}$. Seperti diingatkan Lees-Marshment, kegagalan mewujudkan ekspektasi rakyat yang ditawarkan partai pada saat kampanye akan berdampak pada merosotnya kepercayaan pemilih kepada partai.

Bauran produk lainnya, person (terutama para kader partai yang

107. Www.viva.co.id., dan www.tempo.co., diakses tanggal 8 Januari 2015.

108. Republika online., www.kompas.com., diakses tanggal 7 Januri 2015. 
duduk di parlemen) juga gagal mendukung positioning sebagai partai "Wong Cilik". Sebab pada masa pemerintahan Megawati inilah justru banyak kader PDIP yang terjerat korupsi, suatu perilaku yang memudarkan kepercayaan rakyat bahwa PDIP sungguh-sungguh akan membela dan bekerja untuk rakyat. Selain itu, kepemimpinan Megawati yang cenderung kaku, arogan dan terkesanjudesjugamakinmenegasikan posisi person sebagai bagian dari bauran produk politik yang mestinya dapat memberikan insentif politik kepada partai. Bauran produk politik yang lain, party adalah "sebelasduabelas" dengan performa dan kinerja para kader partai baik di pemerintahan maupun di parlemen; tidak memberikan efek positif dan insentif politik bagi kepentingan masa depan partai. Sementara bauran produk yang terakhir, presentation, penulis melihat pada waktu itu PDIP (bahkan juga partai-partai lain) tampaknya belum sepenuhnya "menyadari" arti penting "menghadirkan dan menyajikan" produk-produk politik dengan kemasan yang didesain sedemikian rupa sehingga menarik minat konsumen (pemilih).

Demikianlah, pada Pemilu 2004 suara PDIP terjun bebas dari angka $33,74 \%$ ke angka $18,53 \%$. PDIP juga gagal memenangi Pemilu, baik legislatif maupun eksekutif. Di Pileg PDIP dipecundangi Golkar yang berhasil merebut posisi pertama; sementara di Pilpres, Megawati (yang berpasangan dengan K.H. Hasyim Muzadi) dipecundangi SBY-JK. Lebih tragis lagi, penurunan perolehan suara dan kekalahan ini terus berlanjut pada Pemilu 2009. Di Pileg, suara PDIP kembali turun ke angka 14,03\% dan hanya menempati posisi ketiga dibawah Golkar (posisi kedua; 14,45\%) dan Demokrat yang berhasil menyodok ke puncak klasemen Pemilu dengan raihan suara cukup meyakinkan : 20.85\%. Sementara di Pilpres, lagilagi Megawati (yang bertandem dengan Prabowo) dipecundangi SBY (yang berpasangan dengan Boediono).

Kekalahan beruntun dalam dua kali Pemilu itu pastilah bukan tanpa sebab dan alasan. Faktor penyebab kekalahan itu pastilah juga tidak tunggal. Tetapi dalam perspektif marketing politik, kekalahan beruntun PDIP dalam dua kali Pemilu setelah berjaya di Pemilu pertama era reformasi itu, menurut hemat penulis adalah lebih karena kegagalannya mengelola positioning yang mereka pilih dan canangkan dengan meyakinkan sebagai partai "Wong Cilik" pasca kemenangannya pada Pemilu 1999. Sementara pilihan model strategi yang cenderung lebih mengandalkan produk politik (product oriented party) terutama figur sentral dan ketokohan Megawati terbukti tidak cukup efektif. Sosok Megawati pada Pemilu 2004 mulai pudar seiring dengan mulai munculnya figur-figur baru yang popular seperti Soesilo Bambang Yudoyono (SBY). 


\section{Partai Demokrat :}

\section{Kegagalan Membangun Positioning dan Produk Politik yang Telah Kehilangan Magnitude}

Menjelang Pemilu 2004, kesadaran akan pentingnya strategi memasarkan partai dan para kandidatnya, terutama melalui media (cetak, elektronik maupun online), mulai tumbuh di kalangan partai politik. Pada era pertumbuhan kesadaran inilah Partai Demokrat lahir; dirikan tanggal 9 September 2001, dan dideklarasikan tanggal 17 Oktober 2002 di Jakarta. ${ }^{109}$ Pemilu 2004, Partai Demokrat hadir sebagai salah satu partai peserta baru.

\section{Hasil Pemilu 2004} menempatkan Demokrat pada urutan kelima di bawah Golkar, PDIP, PKB dan PPP, dengan prosentase perolehan suara sebesar 7,46\%. Posisi ini mengatasi beberapa partai lama seperti PKS, PAN, dan PBB yang masing-masing berada pada posisi keenam, ketujuh dan kedelapan. Keberhasilan ini tidak terlepas dari keberadaan dan pengaruh SBY sebagai tokoh sentral sekaligus icon partai, yang pada waktu itu, telah muncul sebagai "bintang baru" di panggung kepolitikan nasional. Itu sebabnya, meski tidak memuncaki klasemen hasil Pemilu, dengan modal politik popularitas ketokohan SBY, Demokrat cukup "PD” (Percaya Diri) untuk maju sebagai Capres 2004.

Dan hasilnya memang mengejutkan. Meski hanya didukung oleh PBB dan PKPI pada putara pertama; dan mendapat tambahan dukungan informal dari PKS dan PAN pada putaran kedua ${ }^{110}$, pasangan SBYJK berhasil mengungguli 4 pasangan lain yang didukung oleh paket-paket koalisi yang suaranya relatif lebih besar; disamping figur-figur CapresCawapresnya yang juga merupakan nama-nama besar seperti MegawatiHasyim Muzadi, Amien Rais-Siswono Yudohusodo, Wiranto-Salahuddin Wahid, dan Hamzah Haz-Agum Gumelar. ${ }^{111}$

Memimpin pemerintahan lima tahun tidak disia-siakan oleh SBY untuk mengokohkan keberadaan partainya. Dan menjelang Pemilu 2009, Demokrat berada level puncak kepercayaan diri politiknya. Maka slogan "Bersama Kita Bisa" yang dijual pada Pilpres 2004 pun diperbarui dengan slogan baru yang sangat "berani": "Katakan Tidak pada Korupsi". ${ }^{112}$ Dalam perspektif marketing politik, ini adalah bagian dari sinyal positioning. Demokrat ingin mengatakan kepada rakyat, bahwa mereka bukan saja bisa

109. Www.demokrat.or.id., diakses tanggal 7 Januari 2015.

110. Www.viva.co,id., dan Republika.online, diakses tanggal 7 dan 8 Januari 2015.

111. Tabrani Syabirin, dkk., Pemilu Presiden 2004., Jakarta : KPU RI, 2005.

112. Www.tempo.co., dan Kompas.com., diakses tanggal 8 Januari 2015. 
menghadirkan kesejahteraan dan kemajuan bersama bagi rakyatnya (Bersama Kita Bisa), tetapi juga sanggup menjaga amanah rakyat untuk menciptakan pemerintahan yang bersih dari penyakit paling akut bangsa ini : korupsi (Katakan Tidak pada Korupsi). Hasilnya, Pemilu 2009 memang menjadi milik Demokrat. Partai ini berhasil memuncaki klasemen dengan raihan suara 20,85\%, mempecundangi dua kompetitor utamanya : Golkar (14,45\%) dan PDIP $(14,03 \%)$.

Mirip dengan PDIP pasca keberhasilannya memenangi Pemilu 1999, Demokrat juga tidak dapat mengelola positioning ini dengan baik. Slogan berani : "Katakan Tidak pada Korupsi" dalam perjalanan pemerintahan SBY periode kedua (2009-2014) kemudian justru paradoks dengan fakta yang terjadi. Sejumlah elit partai ini, mulai dari Ketua Umum hingga para "bintang iklan" slogan itu, terseret kasus korupsi besar dalam berbagai proyek pemerintah. Pengaruhnya sangat nyata, seperti ditunjukkan berbagai lembaga survei : perlahan tapi pasti, Demokrat mulai kehilangan kepercayaan publik.

Setelah positioning sebagai partai bersih dan anti-korupsi tidak mungkin lagi dipertahankan karena terbukti banyak elit dan kadernya yang justru terlibat banyak skandal korupsi, maka menjelang Pemilu 2014 Demokrat tidak lagi menggunakan slogan berani itu. Sementara untuk mendesain pilih- an positioning baru tent u tidak mudah, mengingat pemerintahannya di periode kedua merupakan pemerintahan koalisi besar yang masing-masing partai tentu merasa memiliki andil atas prestasi pemerintahan itu.

Menurut hemat penulis, ada dua modal besar yang diharapkan para elit Demokrat yang masih bisa menyelamatkan partainya ditengah badai skandal korupsi itu. Pertama adalah program dan kebijakan-kebijakan pemerintahan SBY-Boediono yang Pro Rakyat (seperti PNPM, KUR, BOS, Raskin, BPJS). Kedua, figur SBY yang magnitude politiknya diyakini masih berada diatas tokoh-tokoh partai lain. Maka menjelang Pemilu 2014, tanpa positioning yang jelas, distinctive, dan meaningful, Demokrat kemudian lebih mengandalkan diri pada produk-produk politik yang mereka miliki dan diyakini akan menjadi unggulan dibandingkan dengan produk politik partai lain. Dalam perspektif Lees-Marshament, Demokrat menggunakan model strategi POP (Product Oriented Party); strategi marketing yang mengandalkan kekuatan produk politik, dalam hal ini adalah figur SBY dan programprogram pemerintahan SBYBoediono.

Masalahnya kemudian, sebagai tokoh, SBY tentu masih unggul. Tetapi sebagai nakhoda dan icon partai, SBY tidak lagi memiliki kepentingan politik langsung dengan pribadinya mengingat ia bukan dan 
tidak mungkin maju kembali sebagai Presiden. Sementara persons lain sebagai bagian dari bauran produk politik, praktis tidak dapat diandalkan setelah tadi itu, demikian banyak elit partainya yang terseret kasus korupsi. Kemudian, bauran produk lainnya, policy, didepan sudah disinggung, bahwa pemerintahan SBY-Boediono adalah pemerintahan koalisi. Jadi dengan logika politik yang sederhana, program-program pro-rakyatnya itu tentu tidak mudah untuk diklaim sebagai milik Demokrat sendirian. Kalaupun bisa (sekedar klaim), hal ini tidak akan memberikan efek yang signifikan dalam menopang keberhasilan marketing politik.

Maka demikianlah yang terjadi. Pemilu 2014 menjadi pemilu yang memilukan bagi Demokrat, mirip dengan nasib PDIP pada Pemilu 2004 dan 2009. Dari posisi sebagai partai pemenang pada Pemilu 2009 dengan raihan suara 20,85\%, Demokrat terjun dengan parasut bocor ke posisi empat dengan raihan suara hanya $10,19 \%$. Dan boleh jadi seperti juga yang dialami PDIP, kekalahan tragis ini sangat mungkin disebabkan oleh berbagai faktor penyebab. Tetapi dalam perspektif marketing politik, penulis melihat kegagalan Demokrat mempertahankan prestasi dan reputasinya sebagai partai politik modern pada Pemilu 2014 lebih karena ketiadaan positioning yang jelas, disamping terlalu percaya/mengandalkan diri pada produk politik yang justru sudah "kadaluarsa" dan tidak lagi memiliki magnitude politik yang kencang.

\section{KESIMPULAN}

Kesimpulan

Marketing Politik (Political Marketing) pada hakekatnya merupakan serangkaian aktifitas dalam rangka memperkenalkan, menawarkan dan memasarkan produk-produk politik (ideologi, platform, program, kandidat dll) dengan menggunakan prinsip, prosedur dan tekni-teknik marketing dalam dunia bisnis/komersil, dengan harapan produk-produk politik itu diminati dan kemudian dipilih oleh electorate sebagai "konsumen" dalam pasar politik.

Berdasarkan perspektif/pendekatan Marketing Politik, kegagalan PDI Perjuangan dalam mempertahankan posisinya sebagai partai pemenang Pemilu 1999 pada pelaksanaan Pemilu 2004 disebabkan oleh kegagalan partai ini mewujudkan positioning-nya sebagai "Partai Wong Cilik" melalui implementasi manajemen bauran produk politiknya, yang meliputi: policy, person, party dan presentation.

Sementara berdasarkan perspektif/pendekatan yang sama, kegagalan Partai Demokrat mempertahankan posisinya sebagai partai pemenang Pemilu 2009 pada pelaksanaan Pemilu 2014 disebabkan oleh faktor ketiadaan positioning yang khas, jelas dan 
meaningful dari partai ini menjelang Pemilu 2014 setelah gagal mewujukan branding sebagai "Partai yang Berintegritas, Bersih dan AntiKorupsi” pada Pemilu sebelumnya. Pada saat yang sama, sebagai partai yang berorientasi produk (Product Oriented Party) menurut tipologi Lees-Marshment, ketokohan SBY sebagai figur sentral dan icon partai yang diharapkan masih akan menjadi produk unggulan partai, terbukti tidak lagi memiliki magnitude politik yang memadai.

\section{Catatan Kritis}

Sebagai sebuah metode dan prosedur untuk memenangi suatu kontestasi, pendekatan marketing politik menawarkan sejumlah pemikiran dan konsep operasional dan applicable. Pendekatan ini "mengajarkan" kepada, terutama para aktor politik bagaimana strategi dan teknik yang efektif, serta apa saja yang harus dipersiapkan untuk memenangi kontestasi memperebutkan kekuasaan dan jabatan-jabatan politik.

Namun demikian, pendekatan marketing politik bukan tanpa kelemahan. Dari sudut pandang etik misalnya, pendekatan ini bahkan memiliki semacam "cacat bawaaan". "Cacat bawaan" yang dimaksud terletak pada konsep dan perspektif "marketing" (pemasaran) itu sendiri, yang secara genealogis berasal dari, dan sangat khas bersifat komersial- pragmatik sebagaimana naturnya cara pandang ekonomi. Dalam konteks ini, pendekatan marketing politik berpotensi menjadikan aktifitas politik sebagai semata-mata urusan transaksi jual-beli dan isu politik semata-mata sebagai "barang dagangan" atau komoditas yang hanya bernilai ekonomi. Dimensi keluhuran moral-etik dari hakekat kekuasaan, misalnya sebagai alat untuk mewujudkan kesejahteraan; menegakkan hukum dan keadilan; menciptakan tertib dan harmoni sosial; menghargai human dignity dan sebagainya bisa saja kemudian ternegasikan oleh prinsip-prinsip marketing yang serba pragmatik dan kalkulatif secara ekonomi.

Selain itu, penekanan pada prinsip efektifitas dalam mendesain dan memasarkan produk-produk politik dapat saja mengakibatkan aspek-aspek substantif dari kontestasi politik (sebagai ajang kompetisi gagasan dan adu integritas para kandidat atau partai) menjadi pudar oleh tampilan kemasan dan pencitraan. Publik bisa tergiring pada opini dan kepercayaan, bahwa kemasan yang baik adalah pilihan yang baik. Saat yang sama, partai atau para kandidat juga akan terbiasa lebih mengedepankan tampilan yang artifisial daripada isi yang esensial. Dalam konteks ini pendekatan marketing politik dapat menipu para pemilih.

Kaitannya dengan keberadaan dan peran media massa yang sangat strategis sebagai sarana marketing 
dapat mengakibatkan terjadinya distorsi fungsi yang berlebihan dari media massa (terutama cetak dan elektronik) sekaligus pelanggaran berbagai kode etik jurnalistik oleh manajemen media itu sendiri, yang ujungnya bisa merugikan masyarakat. Dalam konteks ini media massa bisa berubah drastis dari posisinya sebagai media informasi, sarana edukasi dan pencerahan yang independen menjadi institusi partisan yang semata-mata berorientasi bisnis.

Akhirnya, pendekatan marketing politik berpotensi besar mengubah esensi dari suatu kontestasi politik (Pemilu) sebagai ajang kompetisi gagasan dan integritas bagaimana membangun tata kehidupan politik yang lebih baik ke depan; mengkonsolidasikan dan mengembangkan demokrasi di dalamnya, ke orientasi kemenangan semata. Dalam konteks ini marketing politik dapat menyuburkan sikap-sikap Machiavellian terutama di kalangan aktor dan elit politik, semata-mata untuk satu target: memenangi kontestasi !

\section{DAFTAR PUSTAKA}

Ahmad, Nyarwi. 2012. Manajemen Komunikasi Politikdan Marketing Politik: Sejarah, Perspektif dan Perkembangan Riset, Pustaka Zaman. Yogyakarta.

Firmanzah. 2008. Marketing Politik: Antara Pemahaman dan Realitas. Yayasan Obor. Jakarta.

Kasali, Rhenald. 1998. Membidik
Pasar Indonesia: Segmentasi, Targeting, Positioning. Gramedia Pustaka Utama. Jakarta.

Lees-Marshment, Jennifer. 2009. Marketing Politics: Prinsiples and Application. Routledge Publication. London.

Mareek, Philip J. 1995. Political Marketing and Communication. John Libbey and Co. London.

Newman, Bruce I., (ed). 1999. Handbook of Political Marketing. New Delhi. Sage Publication Inc. London.

Nimmo, Dan. 1999. Komunikasi Politik: Komunikator, Pesan, dan Media. Rosda Karya. Bandung.

Nursal, Adman. 2004. Political Marketing: Strategi Memenangkan Pemilu. Gramedia Pustaka Utama. Jakarta.

Syabirin, Tabrani dan Farid Gaban. 2005. Pemilu Presiden 2004. KPU RI. Jakarta..

Setiawan, Bambang dan Bestian Nainggolan (eds). 2004. PartaiPartai Politik Indonesia: Ideologi dan Program 2004-2009. Gramedia Pustaka Utama. Jakarta.

Shea, D.M dan Burton, M.J. 2001. Campaign Craft : The Strategies, Tactics, and Art of Political Campaign Management. Preager, Westport.

www.kpu.go.id. www.rumahpemilu. org., republika online., www. kompas.com., www.tempo.co., www.viva.co.id., www.pdiperjuangan.or.id., dan www. demokrat.or.id. 